\title{
MEMPERKUAT MODAL SOSIAL PEREMPUAN DALAM MENGHADAPI BENCANA
}

\author{
Baiq Lily Handayani \\ Program Studi Sosiologi, Fakultas Ilmu Sosial dan Ilmu Politik \\ Universitas Jember
}

Email: baiq.fisip@unej.ac.id

\begin{abstract}
Abstrak
Tujuan penelitian ini adalah melihat kapasitas perempuan dalam menghadapi bencana. Hal ini dikarenakan perempuan seringkali dikatagorikan sebagai kelompok rentan. Kerentanan-kerentanan tersebut, diantaranya disebabkan oleh faktor kultur dan struktur. Namun disisi yang lain, perempuan memiliki kapasitas yang besar dalam menghadapi bencana. Dengan menggunakan teori Modal Sosial dari Michael Woolcock, penelitian ini mengkaji jaringan kelompok perempuan. Metode penelitian menggunakan metode kualitatif. Hasil penelitian menunjukkan bahwa perempuan mempunyai sebuah kapasitas jaringan yakni perempuan terintegrasi dalam kelompok-kelompok kerukunan seperti kelompok pengajian muslimat, kelompok PKK, Kelompok Arisan, dan kelompok pengajian yang lain. Melalui kelompok tersebut perempuan melakukan sharing value, berbagi informasi dan saling menguatkan satu sama lain. Keberadaan kelompok perempuan di masyarakat inilah yang merupakan suatu modal sosial yang seharusnya mampu menjadi media untuk mentransformasi pengetahuan perempuan khususnya pengetahuan kebencanaan. Kelompok perempuan mempunyai kapasitas dalam mengkoordinir anggotanya minimal seminggu sekali, kelompok perempuan ini pula mampu menggalang dana dari anggotanya baik dalam bentuk dana Kas dan dana arisan, selain itu kelompok perempuan mampu menjadi media untuk melakukan trauma healing terhadap anggotanya.
\end{abstract}

Kata Kunci : modal sosial, kelompok perempuan, bencana, kapasitas, Woolcock.

\begin{abstract}
The purpose of this study is to analyze women's capacity in disasters problem. Because women are often categorized as a vulnerable group. These vulnerabilities, which are caused by cultural and structural factors. But on the other, women have a great capacity to deal with disasters. By using the Social Capital theory of Michael Woolcock, this study examines women's networking group. The research method using qualitative methods. The results showed that women have a network capacity that women are integrated in gemeinschaft groups like Muslimat group, Aisiyah, the PKK, Arisan group, and MHTI. Through the group of women sharing value, share information and reinforce each other. The existence of groups of women in this society, which is a social capital that should be able to transform the knowledge of women in particular knowledge of disaster. Women's groups have the capacity to coordinate its members a minimum of once a week, the women's group is also able to raise money from its members in the form of cash funds and fund social gathering, in addition to the group of women capable of becoming a medium to conduct trauma healing to its members.
\end{abstract}

Key Word : Social Capital, Women's Groups, Disaster, Capacity, Woolcock. 


\section{PENDAHULUAN}

Berdasarkan beberapa catatan dari kejadian bencana yang telah terjadi, menguatkan bahwa salah satu kelompok yang paling rentan terhadap dampak dari bencana adalah perempuan dan anak-anak. Seperti saat kejadian gempa di Yogyakarta pada 27 mei 2006 mayoritas korban adalah perempuan lansia, yang pada saat itu berada di dapur untuk menyiapkan sarapan pagi dan terlambat menyadari adanya gempa.

Data Gempa dan Tsunami di Aceh juga menunjukkan, korban perempuan meninggal 30-40 persen lebih banyak dibandingkan laki-laki, karena waktu itu perempuan kebanyakan sedang bekerja di rumah atau tidak cukup kuat untuk berlari ke tempat yang lebih tinggi sembari membawa anak-anaknya yang belum bisa berjalan. (Oxfam, UNFPA, 2005). Data korban dan kerusakan gempa, di dusun Gedongan, Piyungan, Yogyakarta, mayoritas adalah perempuan/ibu-ibu sebanyak 145 orang.

Rendahnya akses informasi dan keterlibatan dalam sosialisasi kebencanaan di tingkat dusun/desa juga menjadi salah satu penyebab. Hasil kajian lapangan yang dilakukan oleh Mahasiswa Sosiologi Universitas Jember, Dia Mutmainnah, tahun 2011 di Desa kali Gedang Kecamatan Sempol, Kab. Bondowoso, menunjukkan tingkat partisipasi perempuan dalam sosialisasi bencana Gunung Api Ijen, adalah sangat rendah. Yakni, hanya sebagian kecil saja dari perempuan yang diundang dan menghadiri kegiatan sosialisasi cara menyelamatkan diri ${ }^{1}$.

Oleh karenanya, pelibatan kelompok masyarakat dalam manajemen bencana dianggap memiliki peran yang cukup efektif, salah satunya melalui peran kelompok perempuan. Seperti yang telah dilakukan oleh Pemerintah Daerah Kabupaten Sumenep dalam upaya mengurangi dampak resiko bencana, Pemda Kabupaten Sumenep membina 117 desa menjadi desa siaga. Program tersebut menggunakan basis kelompok masyarakat yaitu gerakan PKK, Fatayat, Muslimat, Aisyah maupun GOW, dimana kelompok tersebut melakukan inisiasi kegiatan sadar bencana pada kelompoknya masing-masing yang kemudian akan dikoordinasikan pada tingkat kecamatan dan kabupaten ${ }^{2}$. Konsep serupa juga diterapkan di Kabupaten Tulungagung dengan melibatkan PKK, IBI, Bhayangkari, Persid, Fatayat NU, Muslimat NU, Aisyiah dan LDII ${ }^{3}$.

Besarnya kontribusi kelompok-kelompok masyarakat termasuk kelompok perempuan terhadap program pembangunan nasional sudah diakui berbagai kalangan. Peran mereka tersebut sangat riil karena struktur kelompok yang langsung bersinggungan dengan berbagai lapisan masyarakat. Sedemikian besarnya potensi peran dari kelompok masyarakat ini sudah seharusnya diberdayakan dalam program pengurangan resiko bencana di Indonesia.

Hasil penelitian yang dilakukan oleh Handayani ${ }^{4}$ di kecamatan Panti Kab. Jember pasca bencana banjir bandang, menunjukkan bahwa peran kelompok perempuan sangat besar dalam melakukan rekonstruksi dan rehabilitasi pasca bencana. Sebagian besar kelompok perempuan seperti Muslimat, Aisyiyah, kelompok PKK, Kelompok Arisan, muslimah PKS, Muslimah KAMMI, dan juga muslimah HTI, melakukan jaringan kerjasama dalam proses manajemen bencana. Baik itu pada saat kondisi gawat darurat, pasca bencana (rehabilitasi) maupun pasca bencana dalam

\footnotetext{
${ }^{1}$ Skripsi Diah Mutmainnah, mahasiswa sosiologi Universitas Jember.

${ }^{2}$ http://tabloid_info.sumenep.go.id/index.php. Diakses terakhir 22 Agustus 2010

${ }^{3}$ Dinas Kesehatan Tulungagung. 2010-06-01. diakses terakhir 22 Agustus 2010

${ }^{4}$ Baiq Lily Handayani. 2012. Kelompok perempuan sebagai modal social yang potensial dalam manajemen bencana di desa kemiri kecamatan Panti Jember. Tesis tidak diterbitkan.
} 
rangka mitigasi. Bahkan kelompok-kelompok tersebut membantu proses rekonstruksi sistem sosial di pengungsian. Proses trauma healing dan share of value juga dilakukan melalui kelompok pengajian.

Keberadaan kelompok-kelompok perempuan di masyarakat merupakan salah satu bentuk modal sosial yang berperan dalam upaya pengurangan resiko bencana. Beberapa hasil penelitian menunjukkan bahwa peran perempuan dalam bencana mampu memperkuat eksistensi mereka di dalam masyarakat. Sebagai contoh saat badai Mitch datang tahun 1998, perempuan di Guatemala dan Honduras langsung membangun rumah, menyelamatkan persediaan air, dan membangun tempat perlindungan. Pentingnya peran perempuan dalam proses rekonstruksi pasca bencana ini telah mendorong sebuah LSM lokal membuat kampanye strategis ${ }^{5}$.

Dalam buku Perempuan dan Bencana, Pengalaman Yogyakarta (2007: 62) ${ }^{6}$ peran perempuan dalam penanganan bencana dalam hal perjuangannya membentuk dapur umum dilakukan secara spontan oleh ibu-ibu baik yang rumahnya roboh atau tidak, saling membantu demi mencapai tujuan agar keluarganya tidak kelaparan. Selain itu pemrakarsa pembentukan dapur umum khususnya yang didirikan oleh korban adalah kaum perempuan. Para perempuan tersebut adalah orang-orang yang aktif dalam organisasi di tingkat dusun maupun organisasi yang lebih besar di luar daerah tempat tinggal mereka.

Selain itu secara struktur budaya di Indonesia, perempuan di desa ataupun di kota banyak tergabung dalam kelompok-kelompok, misalnya kelompok pengajian, kelompok arisan, kelompok hobby, PKK, Darma Wanita, dan sebagainya yang hal itu dapat berfungsi dalam berbagai macam aspek.
Perkumpulan yang dibentuk kaum perempuan di tingkat kedaerahan dan nasional sangatlah penting jika dimaksimalkan perannya dalam upaya membangun masyarakat. Termasuk keterlibatan perempuan di dalam upaya penanggulangan bencana, misalnya upaya preventif melalui sosialisasi kesiap-siagaan bencana, yang biasa dilakukan melalui berbagai kegiatan kelompokkelompok perempuan di kampung-kampung, seperti: pengajian, PKK, arisan, dan lain-lain. Dan juga keterlibatan perempuan dalam prosesproses diskusi dan pengambilan keputusan berbagai masalah penyelesaian dalam penanggulangan bencana di tingkat lokal/pemerintahan desa. Serta terlebih dari itu semua, saat bencana melanda, bagaimana peran-peran yang telah dipersiapkan itu menjadi siap diaplikasikan terutama untuk mengatasi beberapa persoalan yang muncul di kamp-kamp pengungsian.

Tingginya tingkat partisipasi perempuan dalam berbagai kelompok perempuan, mengindikasikan ikatan solidaritas mereka yang cukup kuat. Demikian juga intensitas pertemuan mereka menjadi suatu modal besar dalam menguatkan eksistensi kelompok serta membangun jaringan kelompok mereka baik secara horizontal dengan kelompok lain maupun secara vertikal dengan pemerintah dan pemilik modal dalam upaya manajemen bencana.

Oleh karena itu, penguatan kapasitas kelompok perempuan mutlak dilakukan. Penguatan kapasitas akan meminimalisisr risiko bencana akibat hazard yang ada. Ketika perempuan secara individu ataupun kelembagaan memiliki kapasitas, maka tingkat ketahanan merekapun akan meningkat. Mereka akan mudah melakukan adaptasi, mengerti cara menyelamatkan diri serta mampu melakukan recovery dengan cepat pasca bencana terjadi.

\footnotetext{
${ }^{5}$ Imam Yudhianto Soetopo. Penanganan bencana berperspektif gender.

http://www.lintasberita.com/Lifestyle/Pendidikan/penanganan-bencana-berperspektif-gender. diakses terakhir 12 januari 2012

${ }^{6}$ Ismay Prihastuti. 09 September 2009. Perempuan dan kebencanaan.

http://www.lp3y.org/pdf.php?pilih=newsletter\&id=177. diakses terakhir tanggal 14 januari 2012
} 


\section{KERANGKA TEORITIK}

Menurut Hawkins dan Maurer, 20097, banyak penelitian yang menunjukkan bahwa selain modal fisik, modal keuangan, modal sumber daya manusia, modal sosial juga sangat diperlukan dalam upaya penanggulangan dampak bencana alam. Apalagi karena bencana alam acapkali menimbulkan dampak sosial, ekonomi dan kesehatan (fisik maupun mental) yang cukup berat. Modal sosial dapat dikenali pada dua tingkatan. Pada tingkat mikro berupa jaringan-jaringan sosial yang memungkinkan seseorang mendapatkan bantuan untuk mengurangi penderitaan akibat bencana yang menimpanya. Pada tingkat ini, modal sosial berperan memungkinkan warga mendapatkan informasi, peringatan dan bantuan untuk menyelamatkan diri ketika bencana terjadi. Begitu pula mendapatkan bantuan tanggap darurat yang dalam jangka pendek berperan mengurangi penderitaan (fisik maupun kejiwaan) selama berada dalam pengungsian.

Pada tingkat makro dalam bentuk kelompokkelompok sosial yang digerakkan oleh warga, yang ditopang norma-norma dan rasa saling percaya, untuk secara bersama-sama dan terkoordinasi mendorong penanggulangan dampak bencana dan pemulihan kondisi sosial-ekonomi seperti sebelum terjadinya bencana. Di tingkat makro, modal sosial memungkinkan warga mengkelompokkan diri untuk lebih berperan dalam menentukan corak penanggulangan dampak sosial dan ekonomi bencana dalam jangka menengah dan jangka panjang supaya sesuai dengan kebutuhan warga serta sesuai kondisi sosial-ekonomi dan budaya setempat.

Warga yang secara sosial-ekonomi lebih kuat sebelum terjadinya bencana secara rata-rata memiliki corak modal sosial yang lebih luas. Mereka umumnya memiliki bridging social capital dan linking social capital yang lebih kuat. Kedua modal sosial ini memungkinkan mereka memiliki jaringan sosial yang lebih lebar termasuk dengan orang-orang maupun lembaga-lembaga kunci yang berperan dalam pengelompokan programprogram penanggulangan dampak bencana. Akibatnya kalangan ini biasanya juga lebih cepat dalam mengakses program-program pemulihan jangka menengah dan jangka panjang.

Sebagai makhluk sosial, setiap individu mempunyai kebutuhan untuk berkelompok. Setiap masyarakat atau komunitas seharusnya memiliki modal sosial, tentu dengan derajat modal sosial yang berbeda antara satu masyarakat (komunitas) dengan satu masyarakat (komunitas) yang lainnya. Ibrahim $(2006)^{8}$ menyebutkan bahwa hakikat modal sosial adalah hubungan sosial yang terjalin dalam kehidupan sehari-hari warga masyarakat, di mana hubungan sosial mencerminkan hasil interaksi sosial dalam waktu yang relatif lama sehingga menghasilkan jaringan, pola kerjasama, pertukaran sosial, saling percaya, termasuk norma dan nilai yang mendasari hubungan sosial tersebut. Pola hubungan sosial inilah yang mendasari kegiatan bersama atau kegiatan kolektif antar warga masyarakat. Dengan demikian, masyarakat tersebut mampu mengatasi masalah mereka secara bersama-sama (partisipasi aktif). Kegiatan bersama (kolektif) antar warga masyarakat dapat terbangun bila terpenuhi ketersediaan elemen-elemen modal sosial. Elemen-elemen pokok modal sosial tersebut antara lain adalah: (1) hubungan saling percaya (trust); (2) jaringan sosial (sosial networks) (3) pranata (institutions); dan (4) resiprositas (pertukaran timbal balik).

\footnotetext{
${ }^{7}$ http://zanikhan.multiply.com/journal/item/12952 diakses terakhir pada 20 November 2011

${ }^{8}$ Tamrin, Husni. dkk. Implementasi Corporate Social ResponsibilityBerbasis Modal Sosial di Sumatera Utara. http://www.coveragefikomup.com/pdf/Coverage_I_006.pdf. Diakses terakhir 13 Januari 2012
} 
Woolcock dan Narayan dalam Vipriyanti (2007), menyatakan bahwa ada empat perspektif modal sosial dalam pembangunan ekonomi, yaitu; (1) pandangan komunitarian (the communitiarian view), pandangan ini menyamakan modal sosial dengan organisasi pada level lokal (seperti asosiasi, klub, dan kelompok-kelompok warga). Modal sosial diukur secara sangat sederhana yaitu melalui jumlah dan kepadatan suatu organisasi dalam komunitas tertentu, semakin banyak akan lebih baik dan selalu memberikan dampak yang posistif terhadap kesejahteraan masyarakat, (2) pandangan jaringan (the networks view), menekankan pentingnya asosiasi vertikal dan horisontal antar individu, dan hubungan di dalam organisasi dan antar organisasi seperti kelompokkelompok komunitas dan perusahaan. Dalam pandangan ini terdapat dua dimensi dasar dari modal sosial pada level komunitas, yaitu yang dikenal dengan bonding social capital (strong intra communities) dan bridging social capital (weak extra community network). Perspektif ini menganggap bahwa masyarakat dapat dicirikan oleh bawaan (endowment) mereka akan kedua dimensi modal sosial tersebut. Perbedaan kombinasi antar kedua dimensi akan mempengaruhi hasil yang diperoleh dari modal sosial, (3) pandangan kelembagaan (the institutional view), berpendapat bahwa jaringan kerja komunitas dan masyarakat sipil, secara luas adalah hasil dari keadaan politik, hukum, dan lingkungan kelembagaan. Pandangan ini telah menghasilkan sejumlah metodologi dan fakta empiris yang kuat namun hanya untuk kebijakan makro, (4) pandangan sinergi (the synergy view), menggabungkan pandangan jaringan dan kelembagaan atas dasar asumsi bahwa tidak satupun pelaku pembangunan (pemerintah, swasta dan masyarakat) akan dapat berjalan sendiri didalam mengakses sumberdaya yang dibutuhkan untuk menciptakan pertumbuhan yang berkelanjutan dan berkeadilan.
Woolcock (1998) mengajukan tiga dimensi dari modal sosial, yaitu: bonding, bridging dan linking sebagai berikut: (1) Modal sosial yang bersifat mengikat (bonding social capital) merujuk pada hubungan antarindividu yang berada dalam kelompok primer atau lingkungan ketetanggaan yang saling berdekatan. Komunitas-komunitas yang menunjukkan kohesi internal yang kuat akan lebih mudah dan lancar dalam berbagi pengetahuan. (2) Modal sosial yang bersifat menjembatani (bridging social capital) adalah hubungan yang terjalin di antara orang-orang yang berbeda, termasuk pula orang-orang dari komunitas, budaya, atau latar belakang sosial-ekonomi yang berbeda. Individu-individu dalam komunitas yang mencerminkan dimensi modal sosial yang bersifat menjembatani akan mudah mengumpulkan informasi dan pengetahuan dari lingkungan luar komunitasnya dan tetap memperoleh informasi yang aktual dari luar kelompoknya. Tipe modal sosial ini menunjuk pada hubungan antar individu yang memiliki kekuasaan atau akses pada bisnis dan hubungan sosial melalui kelompok-kelompok sekunder. (3) Modal sosial yang bersifat mengaitkan (linking social capital) memungkinkan individu-individu untuk menggali dan mengelola sumber daya, ide, informasi, dan pengetahuan dalam suatu komunitas atau kelompok pada level pembentukan dan partisipasi dalam organisasi formal.

\section{MODAL SOSIAL PEREMPUAN}

Sebuah modal sosial memiliki berbagai macam wujud dalam kehidupan sehari-hari, modal sosial itu tertambat pada struktur sosial seperti hubungan sosial, adat dan nilai budaya lokal, toleransi, kesediaan untuk mendengar, kejujuran, kearifan lokal dan pengetahuan lokal, jaringan sosial dan kepemimpinan sosial, kepercayaan, kebersamaan dan kesetiaan, 
tanggung jawab sosial, partisipasi masyarakat serta kemandirian?.

Dengan adanya suatu hubungan sosial individu satu dengan individu yang lain akan saling memperhatikan. Adanya kepedulian dari satu anggota kelompok terhadap anggota yang lain, mengandung nilai positif. Nilai positif tersebut akan menjadi nilai bersama dalam sebuah kelompok tersebut.

Selain itu, dalam sebuah kelompok biasanya memiliki faktor pengikat. Faktor inilah yang menyebabkan para anggotanya terkondisikan atau terpaksa untuk selalu datang. Beberapa kelompok muslimat sengaja mengadakan kegiatan arisan sebagai bagian dari kegiatan mereka. Hal itu sebagai upaya untuk menarik dan mengikat anggota, untuk selalu hadir pada setiap pengajian yang diadakan.

Menurut Lesser (2000) dalam Dede (2008:14), modal sosial sangat penting bagi komunitas karena ia: (1) mempermudah akses informasi bagi angota komunitas; (2) menjadi media power sharing atau pembagian kekuasaan dalam komunitas; (3) mengembangkan solidaritas; (4) memungkinkan mobilisasi sumber daya komunitas; (5) memungkinkan pencapaian bersama; dan (6) membentuk perilaku kebersamaam dan berorganisasi komunitas. Dengan kata lain, trust atau kepercayaan yang bersifat timbal-balik antara seluruh komponen stakeholders menjadi modal yang penting dalam menumbuhkan partisipasi, kerjasama, bahkan kemitraan stakeholders dalam perencanaan pembangunan. Tanpa adanya trust, maka yang terbentuk adalah low trust society, di mana masyarakat tidak mempercayai pemerintah sebagai figur otoritas, dan akibatnya pemerintah kehilangan legitimasinya dalam mewujudkan tertib sosial dalam masyarakat.

Menurut Bain dan Putnam, modal sosial bisa bekerja pada level internal dan eksternal. Pada level eksternal modal sosial bekerja dengan pilar pendukungnya yaitu human capital, financial capital, physical dan cultural capital serta natural capital.

Dengan berkelompok mereka menjalin hubungan sosial, menjalin komunikasi bersama untuk hidup berdampingan sebagai teman, sahabat dan tetangga. Saling menjenguk ketika ada yang sakit, saling membantu ketika ada hajatan, serta saling berbagi informasi dalam berbagai macam hal. Dalam kehidupan sehari-hari terjadi interaksi antar anggota kelompok yang menyebabkan adanya kepedulian antara satu dengan yang lainnya.

Mereka mengakui dengan terlibat dalam kelompok-kelompok tersebut membuat mereka mempunyai banyak teman, ikut menjaga kerukunan, menambah ilmu agama dan juga menjamin diri mereka ketika sakit atau terkena musibah maka, akan ada orang lain yang peduli pada kehidupan mereka. Eksistensi diri merekapun akan terlihat dengan semakin banyak mengikuti kelompok pengajian dan semakin aktif dalam kegiatan kelompok pengajian tersebut. Oleh karena itu, ketidakterlibatan pada sebuah kelompok atau perkumpulan membuat individu merasa terasing dari lingkungannya.

Hubungan dalam kelompok ini bisa menyebabkan adanya rasa empati/kebersamaan. Bisa juga mewujudkan rasa simpati, rasa berkewajiban, rasa percaya, resiprositas, pengakuan timbal balik nilai kebudayaan yang mereka percaya. Rule of law/aturan main merupakan aturan atau kesepakatan bersama dalam masyarakat, seperti sanksi non formal yang akan diberikan masyarakat kepada anggota masyarakatnya berupa pengucilan, rasa tidak hormat bahkan dianggap tidak ada dalam suatu lingkungan komunitasnya. Ini menimbulkan ketakutan dari setiap anggota masyarakat yang tidak melaksanakan bagian dari tanggung jawabnya. Hal ini berakibat

\footnotetext{
${ }_{9}^{9}$ Rudi Hartanto. 2005. http://masroed.wordpress.com/2010/05/26/pengaruh-dan-wujud-pengembangan-modal-sosialuntuk-menciptakan-sistem-politik-yang-dinamis/
} 
akan adanya social order/keteraturan dalam masyarakat.

Peran perempuan dalam kehidupan sosial kemasyarakatan pun cukup besar, misalnya dalam menjalin hubungan ketetanggaan. Ketika ada tetangga yang punya hajat, maka perempuanlah yang lebih dulu datang untuk rewang, ketika ada yang melahirkan maka perempuanlah yang datang jagong bayi, ketika ada yang meninggal maka hubungan secara langsung ke keluarga dijalin oleh perempuan. Demikian juga yang mengantarkan dan menunggu anak-anak di sekolah biasanya adalah ibu-ibu.

Apabila diperhatikan dari sudut pandang human capital, perempuan mempunyai banyak kelebihan, diantaranya mereka cukup telaten dalam mengerjakan tugas-tugas tertentu, mereka lebih banyak berkumpul dengan ibu-ibu yang lain, sehingga informasi dari mulut ke mulut lebih cepat sampai. Selain itu di dalam lingkup keluarga, perempuan lebih dekat dengan anak-anaknya, perempuan lebih mengetahui kondisi rumah tangga, sehingga apabila terjadi bencana perempuan yang lebih siap mempersiapkan barang-barang berharga untuk diselamatkan. Demikian pula ketika bencana telah usai, pemulihan kondisi psikologis keluarga khususnya psikologis anak akan lebih mudah apabila seorang ibu yang menanganinya. Selama ini peran-peran domestik seperti memasak, merawat anak, dan mengurus rumah adalah tugas perempuan. Sedangkan mencari nafkah dan hubungan-hubungan yang bersifat struktural menjadi wewenang dari laki-laki.

Adat dan budaya setempat mengkonstruksi perempuan untuk lebih banyak berperan dalam lingkup domestik. Peran sosial perempuan yang lebih banyak di rumah, menyebabkan lingkup aktifitas perempuanpun berkisar pada urusan rumah tangga. Tugas-tugas mengurus rumah, mengurus anak, memasak menyebabkan sebagian besar waktu mereka habiskan di lingkungan rumah.
Sementara laki-laki bertugas mencari nafkah untuk pemenuhan kebutuhan keluarga.

Peran yang lebih banyak mengurusi urusan rumah tangga, menyebabkan lebih banyak aktifitas di rumah sehingga lebih banyak waktu untuk berkumpul dengan tetangga. Selain itu, keterbatasan akses serta upaya untuk meraih eksistensi diri dalam masyarakat membuat mereka banyak berkumpul dalam beberapa forum. Keberadaan mereka dalam suatu kelompok merupakan suatu keterikatan yang kuat antara sesama perempuan. Oleh karena itu, selain keterikatan yang berdasarkan ikatan keluarga/kekerabatan, ketetanggaan, berdasarkan hobi, suku, etnis, ataupun ikatan demografis, ikatan yang disebabkan oleh jenis kelamin berdasarkan persamaan peran-peran sosial merupakan salah satu bentuk bonding social capital.

Suatu bonding social capital, mempunyai peran yang besar dalam masyarakat. Hal itu karena mereka adalah bagian dari masyarakat itu sendiri. Mereka yang lebih tahu akan kondisi mereka, kebutuhan mereka, kelemahan atau kekuatan mereka serta peluang-peluang mereka. Akan tetapi karena terbatasnya akses yang diberikan, akhirnya mereka cenderung pasif dan bergantung kepada orang lain.

Keterbatasan kemampuan mereka untuk mengakses ke dunia luar, ke pemilik modal, ataupun ke pemerintah membuat mereka bergantung pada orang lain atau kelompok lain. Hubungan yang terjalin diantara orang-orang luar komunitas, luar daerah atau luar kelompok menjadi suatu modal sosial yang bersifat menjembatani. Sehingga memudahkan mereka untuk dapat mengembangkan diri atau kelompok mereka, karena akses informasi, dana dan juga pengetahuan dapat diperoleh.

Peran-peran domestik perempuan sebenarnya merupakan potensi bagi perempuan itu sendiri dalam kehidupan bermasyarakat. Keahlian-keahlian yang mereka miliki seperti memasak, merawat anak, 
kepedulian perempuan serta memfasilitasi perempuan untuk dapat berperan aktif dalam fase persiapan dan penanggulangan bencana, serta fase-fase selanjutnya dapat lebih dimaksimalkan.

Dalam kehidupan sosial, ada pembagian tugas (division of labor), begitu pula dalam kehidupan keluarga karena tidaklah mungkin sebuah kapal dikomandani oleh dua nakhoda. Talcott Parsons dan Bales (1979) berpendapat bahwa keluarga adalah sebagai unit sosial yang memberikan perbedaan peran suami dan isteri untuk saling melengkapi dan saling membantu satu sama lain. Keharmonisan hidup hanya dapat diciptakan bila terjadi pembagian peran dan tugas yang serasi antara perempuan dan laki-laki, dan hal ini dimulai sejak dini melalui pola pendidikan dan pengasuhan anak dalam keluarga.

Subordinasi perempuan yang 'lumrah' berkembang dalam budaya patriarkhi tersebut, menempatkan perempuan pada posisi yang kurang menguntungkan baik dari segi sosial, ekonomi maupun politik. Karena bagaimanapun, posisi ekonomi yang lemah berpengaruh signifikan terhadap proses komunikasi dan negosiasi dalam forum pengambilan keputusan, baik itu di rumah tangga ataupun di masyarakat luas. Sebenarnya, secara sederhana bisa kita analisa bahwa jika saja perempuan dan laki-laki tidak lagi dibedakan peranan gendernya, maka peningkatan ekonomi keluarga maupun skala ekonomi makro didalam pembangunan daerah akan lebih cepat terwujud karena terbukanya kesempatan yang sama bagi perempuan dan laki-laki dalam mendapatkan manfaat dan prioritas dari hasil-hasil pembangunan.

Menurut Engels, akumulasi kepemilikan dan kontrol laki-laki terhadap produksi merupakan sebab paling mendasar terjadinya subordinasi perempuan. Keunggulan laki-laki atas perempuan adalah hasil keunggulan kaum kapitalis atas kaum pekerja. Penurunan status perempuan mempunyai korelasi dengan perkembangan produksi dan perdagangan.
Perempuan tidak perlu hadir di pertemuan adat. Logikanya, jika dalam kepengurusan adat terdapat perempuan yang juga ikut sebagai pengambil keputusan, tentu akan lebih baik lagi karena kemudian masalah-masalah dan kepentingan perempuan yang ada dalam lingkup adat tersebut juga lebih diperhitungkan dan dianggap sebagai kepentingan bersama (umum). Bukankah perempuan yang lebih tahu tentang masalah perempuan itu sendiri? Jika kemudian mereka tidak pernah dilibatkan dalam pengambilan keputusan yang berhubungan dengan dirinya, bukankah tidak mungkin apa yang dianggap tidak penting oleh pengurus adat laki-laki ternyata merupakan hal yang sangat penting bagi perempuan? Dan bukan tidak mungkin juga keputusan adat yang dibuat bisa merugikan perempuan karena ketidakhadiran perempuan di dalam forum untuk menyampaikan pendapatnya.

Secara ringkas, beberapa penyebab kerentanan perempuan terhadap bencana yaitu: (a) Pengetahuan mengenai bencana rendah, (b) Pengetahuan mengenai cara menyelamatkan diri, (c) Tangguh jawab di rumah, (d) Tanggung jawab terhadap anak, (e) Lemah secara ekonomi, (f) Akses terhadap sumber informasi rendah (g) Proses pengambilan keputusan, (h) Konstruksi sosial dan peran perempuan, (h) Pembagian kerja dalam masyarakat, (i) Kodrat perempuan sebagai ibu: Hamil, Menyusui, Menstruasi, (j) Rendahnya keterlibatan perempuan di forum formal.

\section{POTENSI KAPASITAS PEREMPUAN (KELOMPOK PEREMPUAN) DALAM MENGHADAPI BENCANA}

Potensi kapasitas perempuan (kelompok perempuan) diantaranya mempunyai kapasitas dalam sosialisasi, kapasitas penguatan anggota, transformasi, dan kapasitas pengelolaan ekonomi. 
Akan tetapi sejauh ini kapasitas tersebut belum dimanfaatkan untuk peningkatan kapasitas perempuan mengenai bencana. Program-program atau agenda kegiatan merekapun sifatnya belum menjadikan isu kebencanaan sebagai salah satu isu.

Kelompok Dama/PKK, mempunyai kapasitas sosial yang dapat memberikan akses kepada perempuan untuk berpartisipasi dalam rapat-rapat desa. Dalam hal ini kelompok Dama/PKK menjadi bridging/jembatan akses dan informasi bagi perempuan dan pemerintah, terutama kaitannya dengan program sosialisasi kebencanaan.

Kelompok pengajian muslimat, mempunyai kapasitas sosial yang berfungsi dalam sosialisasi, penguatan ruh keagamaan anggota, penguatan integritas anggota, meningkatkan kerukunan antar anggota, sebagai media interaksi dan sosialisasi, dan sebagai media eksistensi diri. Oleh karena itu, kelompok pengajian muslimat ini dapat menjadi bonding social capital. Sedangkan kelompok arisan berperan dalam pengelolaan ekonomi perempuan. Melalui kelompok arisan ini perempuan di lingkungan Kauman menyisihkan uang untuk ditabung.

Sudah saatnya pemerintah melakukan kerjasama dengan kelompok-kelompok perempuan dalam mentransformasi pengetahuan masyarakat tentang bencana. Pemerintah dapat meningkatkan kapasitas perempuan, pada setiap tahapan manajemen bencana.

1) Pada tahap mitigasi dan kesiapsiagaan; pemerintah dapat memanfaatkan pertemuanpertemuan PKK/Dama, pengajian dan arisan sebagai media sosialisasi kebencanaan. Baik itu mengenai tanda-tanda bencana, kondisi lingkungan sekitar, cara menyelamatkan diri dan keluarga dan barang-barang yang harus dipersiapkan.

2) Pada tahap response/tanggap darurat; jika di daerah tersebut terjadi bencana dan mereka menjadi bagian dari korban.
Mereka telah mengetahui cara-cara menyelamatkan diri, telah membantu menyelamatkan barang-barang berharga dan melakukan evakuasi sesegera mungkin, meskipun suami sedang tidak ada di rumah. Oleh karena itu, pemerintah melalui kelompok perempuan dapat memberikan simulasi bencana, pelatihan keterampilan mendirikan tenda, pelatihan memasak di dapur umum, pelatihan cara melakukan pertolongan pertama pada orang sekitar dan pelatihan traumatic healing. Sehingga apabila mereka bukan merupakan bagian dari bencana, mereka dapat segera memberikan bantuan kepada korban bencana.

3) Pada tahap recovery/pemulihan; Hasil penelitian yang peneliti lakukan sebelumnya di Desa Kemiri Kec. Panti, menunjukkan bahwa kelompok pengajian, Dama dan arisan memiliki peranan yang sangat penting dalam pemulihan korban bencana. Karena melalui forum-forum tersebut mereka dapat saling menguatkan, mengingatkan dan saling berbagi tentang apa saja. Oleh karenanya, pemerintah dapat memaksimalkan peran dari kelompok perempuan dengan cara meningkatkan kapasitas yang mereka miliki.

\section{PERAN PEREMPUAN (KELOMPOK PEREMPUAN) SEBELUM BENCANA}

\section{Melakukan Persiapan di Rumah}

Perempuan adalah manager dalam rumah tangga. Setiap detil rumah, perempuan (isteri) yang lebih paham dari pada suami. Kesehariannya menjadikan hal tersebut menjadi mudah dan melekat. Setiap hari ia yang menyapu setiap sudut rumah, mengelap kaca, membersihkan lubang angin, menata tempat tidur, menata lemari, menata dapur, mendampingi anak belajar, 
menasehati, mengedukasi dan lain sebagainya. Sehingga setiap perempuan mengetahui bagian dari rumahnya yang bocor, listrik mana yang konslet, tembok sebelah mana yang retak, kaca jendela yang retak, genteng yang pecah dan melorot, kayu-kayu rumah yang keropos, lemari yang dimakan rayap, lantai yang licin, saluran pembuangan yang macet, bau air sumur/PAM, termasuk juga berapa saving keluarga untuk hidup beberapa bulan kedepan, stok beras, sabun, gula, minyak, terasi dan lain sebagainya. Intinya perempuan selain sebagai manager dalam keluarga juga merupakan bendahara, sekretaris, perawat, pengasuh, guru, pengelola, pembantu, tukang masak, tukang cuci, tukang sapu, dan banyak lagi tugas dan peran yang diembannya.

Oleh karenanya, sudah seharusnya perempuan menjadi sosok yang peka terhadap bencana. Perempuan sebagai manager di rumah, hendaknya mengetahui dimana lokasi aman dan lokasi rawan dalam rumahnya, bagaimana cara memasang figura supaya aman dan tidak membahayakan, bagaimana cara memasang lemari supaya tidak mudah roboh, bagaimana cara menyambung kabel listrik agar tidak konslet, dimana meletakkan rak piring agar tidak mudah jatuh dan pecah, dan hal lainnya. Perempuan juga harus mengetahui, hal apa yang harus dimiliki di rumahnya agar rumahnya aman dari bencana. Misalnya di rumah harus memiliki meja kayu yang cukup besar untuk tempat berlindung jika terjadi bencana, atau perempuan harus tahu dan memberi tahu anggota keluarga terutama anak anaknya pintu darurat jika harus segera keluar rumah saat bencana, perempuan harus mengetahui bagaimana cara memadamkan api apabila kebakaran, perempuan harus mengetahui bagaimana cara memasang tabung gas dengan benar, dan hal-hal lainnya yang merupakan keseharian perempuan di rumah.

Selain itu, tugas perempuan sebagai ibu, isteri, anak dan anggota keluarga adalah memastikan anggota keluarganya mengetahui tentang kondisi rumah, cara menyelamatkan diri, lokasi aman, lokasi rawan, titik kumpul, nomor-nomor darurat, dan lain sebagainya. Ibu harus mengajar anaknya nama-nama anggota keluarga, terutama nama ayah ibu, alamat rumah dan no HP.

\section{Melakukan Sosialisasi Lewat Kelompok}

Hampir setiap perempuan adalah bagian dari kelompok, baik pengajian, kelompok kerja, kelompok usaha, kelompok masyarakat dan sebagainya. Kelompok perempuan mempunyai peran sebagai media sosialisasi, media interaksi dan komunikasi, media eksistensi diri, media meningkatkan ruh keagamaan, serta meningkatkan integritas dan kerukunan antar anggota. Hampir setiap minggu mereka bertemu, dan duduk bersama. Mereka melakukan interaksi dan hubungan social, menjalin komunikasi dan hidup berdampingan sambil melakukan sharing value.

Sehingga kelompok-kelompok perempuan ini menjadi sarana yang penting bagi mereka untuk mengenal tetangganya, mengetahui kondisi masyarakat dan lingkungan dan juga mengetahui informasi-informasi terbaru. Mekanisme pertemuan yang dilakukan oleh Dama dan kelompok pengajian yang menggunakan sistem anjangsana, memudahkan mereka untuk semakin mengenal satu sama lain.

Pemerintah seharusnya dapat mengoptimalisasi peran dari kelompok PKK/Dama dalam mentransformasi pengetahuan kebencanaan perempuan dan masyarakat. Sebaliknya PKK dapat bekerja sama dengan kelompok-kelompok pengajian dan arisan, sebagai kelompok bonding social yang bersentuhan langsung dengan masyarakat. Sedangkan perempuan sebagai agen dalam keluarga dapat mentransformasi pengetahuannya kepada anggota keluarga, baik itu anak, orang tua, saudara, suami dan anggota keluarga yang lain. Sehingga berbagai lembaga 
tersebut dapat bersinergi dalam membentuk Secara singkat sinergitas kelompok perempuan masyarakat yang sadar dan siaga bencana. itu dapat dilihat dalam skema di bawah ini:

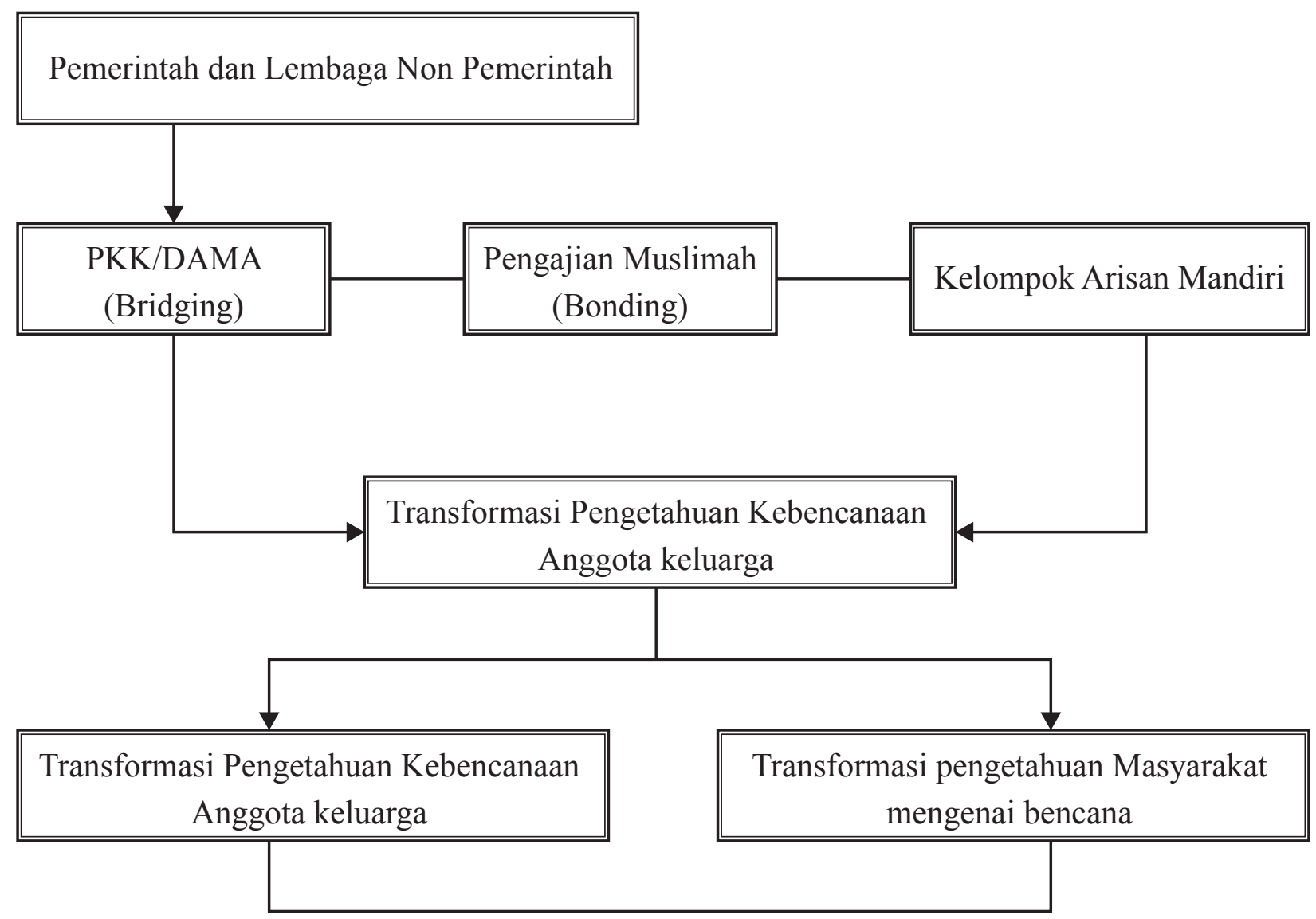

Skema 1. Model Peran Pengajian Muslimah dan PKK sebagai Media Transformasi Pengetahuan Perempuan dan Masyarakat Mengenai Bencana

\section{PERAN PEREMPUAN (KELOMPOK PEREMPUAN) SAAT BENCANA}

Tahap tanggap darurat (Emergency Response) merupakan tahap saat terjadi bencana yang mencakup kegiatan tanggap darurat untuk meringankan penderitaan sementara, seperti search and rescue (SAR), bantuan darurat, evakuasi dan pengungsian. Fase bencana terbagi atas:

- Fase dampak/Fase panik

Pada fase ini dampak dari bencana dirasakan oleh masyarakat terpapar, keluarganya dan juga pemerintah setempat. Pada fase ini biasanya masyarakat terpapar bencana dalam kondisi panik dan cenderung belum bisa melakukan upaya-upaya konstruktif. Masyarakat korban bencana dikatagorikan menjadi tiga katagori (Maarif, 2015): pertama, masyarakat yang mempunyai ketangguhan dan mampu secara sosial mengontrol kondisi saat bencana terjadi. Singkatnya, masyarakat setempat mampu secara mandiri mengatasi bencana yang melanda dan segera bangkit kembali (Bounce back). Kedua, adalah keadaan dimana masyarakat perlu intervensi dari 
pihak eksternal, namun hal itu hanya diperlukan pada saat periode panik yang terjadi selama 3 hingga 7 hari. Pada periode ini biasanya ditandai dengan kurang terpenuhinya kebutuhan dasar masyarakat berupa sandang, pangan, obat-obatan, papan, air, lisrik, komunikasi, transportasi, sanitasi, dan sebagainya. Namun begitu pola penanganan saat tanggap darurat telah dikenali, maka masyarakat setempat dengan bimbingan pemerintah daerahnya telah mampu menangani kesulitannya sendiri. Ketiga, masyarakat yang benar-benar terpuruk karena bencana. Pemerintah daerahnya pun lumpuh total. Sumber-sumber daya yang dimiliki telah lenyap. Untuk katagori ini, intervensi pemerintah dan pihak ekternal sangat dibutuhkan dari awal masa tanggap darurat hingga fase rehabilitasi dan rekonstruksi.

- Fase heroic

Merupakan fase dimana banyak perilaku penyelamatan heroic muncul dalam fase ini. Banyak orang datang untuk menolong dan menyelamatkan korban, baik korban hidup maupun meninggal, termasuk menyelamatkan binatang. Pada fase ini orang-orang mengalami tingkat aktivitas yang tinggi namun produktivitasnya rendah. Berkembang rasa altruisme dan keinginan untuk saling memberi bantuan tanpa diminta, baik itu berupa bantuan tenaga, maupun harta. Pada fase ini dampak sosial dan psikologis dari bencana dirasakan seperti hilangnya anggota keluarga, tulang punggung dalam keluarga, orang-orang yang disayangi, juga hilangnya perangkat desa sehingga menyebabkan terganggunya tatanan sosial masyarakat. Pada tahap ini, kelompok perempuan dapat membantu untuk:

1. Mengidentifikasi korban, penanganan jenazah perempuan.
2. Menginventarisir kebutuhan perempuan, seperti pakaian yang layak pakai sesuai adat dan budaya, pakaian dalam perempuan, pembalut untuk menstruasi, makanan dan susu bayi, selimut, perlengkapan shalat.

3. Mengidentifikasi kondisi pengungsi perempuan: Luka, trauma, pencarian anggota keluarga.

- Fase bulan madu

Pada fase ini bantuan atas korban bencana sudah mulai tersedia dan berdatangan. Banyak bantuan yang datang baik dari pemerintah, swasta amupun perseorangan berupa makanan, minuman, obat-obatan, pakaian, tenda, selimut, dan logistik lainnya. Ikatan kommunitas mulai berkembang karena merasa senasib dan sepenanggungan Harapan optimis mulai muncul dan timbullah kenyakinan bahwa kondisi normal akan dating. Pada tahap inilah peluang layanan konseling untuk memperkuat identitas sangat berpengaruh dan membangun hubungan dengan stake holders.

- Fase kekecewaan

Pada fase ini, korban bencana mulai bergeser dari fase bulan madu ke kekecewaan. Para korban bencana mulai menyadari dan merasakan keterbatasan bantuan bencana yang tersedia. Kelelahan fisik pun mulai meningkat, ketidaknyamanan di pengungsian karena tempat tinggal yang bercampur baur, antri MCK, kebosanan dengan situasi baik makanan, maupun situasi pengungsian. Optimisme berganti dengan keputusasaan. Peningkatan kebutuhan untuk layanan pokok mulai meningkat pada fase ini.

Pada fase ini, perlu ada pendampingan dari kelompok pengajian untuk melakukan upaya recovery, trauma healing, membentuk kelompok untuk sharing, merencanakan masa depan, membuat pelatihan-pelatihan 
ekonomi seperti membuat makanan, kerajinan tangan, dan lain sebagainya sebagai modal mereka untuk bangkit pasca bencana.

Pada fase ini, kelompok perempuan dapat melakukan intervensi kepada korban bencana terutama kepada ibu-ibu dengan dengan cara membangun jaringan dengan kelompok luar maupun dengan pihak pemodal. Selain itu, kelompok perempuan dapat menginisiasi perpustakaan untuk anak-anak, serta membantu memasarkan produk hasil karya pengungsi.

- Fase rekonstruksi dan Fase rehabilitasi

Fase ini merupakan sebuah fase dimana pemerintah melakukan perbaikan terhadap sarana pra sarana infrastruktur. Perempuan juga seharusnya dapat terlibat secara aktif dengan berkoordinasi dengan pemerintah seperti BPBD dalam kluster-kluster seperti kluster logistik, kluster komunikasi, kluster perawatan jenazah perempuan, kluster kesehatan, kluster kelompok rentan, kluster trauma healing, kluster dapur umum, kluster media center/ call center, dan kluster lainnya. Peran kelompok perempuan pada tahap tanggap darurat ini sangat diperlukan. Terutama peran pendampingan terhadap perempuan dan anak-anak.

\section{PERAN PEREMPUAN (KELOMPOK PEREMPUAN) PASCA BENCANA}

Dalam proses recovery, rehabilitasi dan rekonstruksi kondisi sosial ekonomi masyarakat pasca bencana, banyak pihak yang terlibat. Baik itu pihak pemerintah daerah, maupun LSM yang banyak berdatangan. Oleh karena itu, sangat penting sekali dalam proses rehabilitasi dan rekonstruksi pasca bencana dapat dilakukan dan dikelola secara bersama-sama tidak hanya lintas sektoral, melainkan juga harus melibatkan seluruh masyarakat (stakeholders) yang ada di desa Kemiri kecamatan Panti khususnya dan Kabupaten Jember pada umumnya.

Dalam perspektif penanggulangan bencana yang berbasiskan pada masyarakat, semua potensi yang ada harus dioptimalkan. Baik itu human capital, social capital, financial capital, natural capital maupun physical capital. Semua aset tersebut merupakan satu kesatuan kerja, yang saling membutuhkan satu sama lain. Proses pemulihan (recovery) adalah proses pemulihan darurat kondisi masyarakat yang terkena bencana, dengan memfungsikan kembali prasarana dan sarana pada keadaan semula. Upaya yang dilakukan adalah memperbaiki prasarana dan pelayanan dasar (jalan, listrik, air bersih, pasar puskesmas, dan lain-lain).

Sedangkan rekonstruksi adalah program jangka menengah dan jangka panjang guna perbaikan fisik, sosial dan ekonomi untuk mengembalikan kehidupan masyarakat pada kondisi yang sama atau lebih baik dari sebelumnya. Selanjutnya rehabilitasi adalah upaya langkah yang diambil setelah kejadian bencana untuk membantu masyarakat memperbaiki rumahnya, fasilitas umum dan fasilitas social penting, dan menghidupkan kembali roda perekonomian.

Potensi-potensi kelompok penting dalam optimalisasi peran dan fungsi kelompok perempuan di masyarakat. Khususnya untuk menghadapi permasalahan di sekitar mereka, seperti permasalahan lingkungan. Masyarakat yang terbagi dalam kelompok-kelompok sosial yang berada dalam suatu ikatan solidaritas (bounded solidarity) yang di dalamnya terjadi pola hubungan dan kerjasama yang kuat dalam berbagai hal. Kemampuan anggota-anggota kelompok untuk mengorganisir diri dan melakukan pola hubungan satu sama lain akan menjadi sebuah kekuatan yang sangat penting, bukan hanya bagi kerukunan antar anggota 
namun juga aspek ekonomi, keagamaan dan aspek sosial yang lain.

Serangkaian nilai-nilai dan aturan-aturan bersama yang dianut oleh anggota kelompok meningkatkan ikatan antara mereka. Nilai-nilai dan aturan-aturan tersebut dalam istilah Fukuyama disebut sebagai social glue (perekat sosial). Setiap anggota kelompok saling mengingatkan untuk selalu hadir dan mencari tahu mengapa salah satu anggota tidak hadir. Selain itu adanya kebiasaan saling menjenguk ketika sakit, saling membantu ketika sedang membutuhkan bantuan, melayat bila ada yang meninggal dan koleman ${ }^{10}$ pada saat ada hajatan merupakan suatu modal sosial yang sangat penting dalam masyarakat. Hubungan diantara mereka diikat oleh suatu kepercayaan, saling membutuhkan, saling pengertian, dan adanya nilai serta motivasi bersama yang dianut diantara mereka.

Kelompok perempuan juga memanfaatkan instrumen agama dalam memperkuat ikatan sosial pasca bencana. Kegiatan seperti ini sangat menunjang pemulihan para korban yang selamat, dengan diselenggarakan kegiatan tahlilan keluarga korban akan merasa tenang, dan lebih ikhlas dalam menerima kondisi pasca bencana. Karenanya proses recovery moral dan metal akan lebih cepat bila dilakukan dengan kegiatan-kegiatan demikian.

Ikatan sosial dalam kelompok ini juga terlihat dalam aktifitas-aktifitas yang dilakukan oleh kelompok perempuan ketika terjadi bencana. Perekat sosial dalam kegiatan keagaman merupakan salah satu instrumen yang dijumpai pada masyarakat Panti pasca bencana.

Bonding social mereka kembali menguat pasca terjadinya bencana, khususnya ketika mereka berada di perumahan. Kondisi tempat tinggal yang baru, tetangga baru, pola pemukiman yang baru serta kebiasaan-kebiasaan yang baru. Menuntut setiap anggota struktur social tersebut untuk mampu bertahan hidup (beradaptasi).

Sebuah struktur sosial selain membutuhkan anggota, juga membutuhkan pranata/institusi sosial sebagai media mengatur kehidupan para anggotanya. Ketiadaan pranata/institusi membuat kehidupan bermasyarakat menjadi kurang terarah. Karenanya beberapa bulan setelah menempati perumahan mereka mulai menghidupkan kembali institusi sosial mereka. Diantaranya dengan membentuk kembali kelompok-kelompok muslimatan, arisan, dama, PKK, kelompok tahlilan dan juga struktur terendah dalam pemerintahan seperti RT/RW.

Peran perempuan sangatlah strategis, ketika salah satu anggota keluarga yang mengalami trauma maka seorang ibu atau seorang isteri memiliki peran yang sangat besar dalam memulihkan kondisi anggota keluarga yang lain. Seorang ibu yang menguatkan dan mengingatkan anggota keluarga yang lain. Pada saat bencana Panti terdapat ibu-ibu yang memang fokus melakukan kegiatan penghilangan trauma (traumatic healing), mereka adalah ibu-ibu yang berasal dari ACT (Aksi Cepat Tanggap).

Peran kelompok perempuan dalam manajemen bencana dapat didorong agar lebih kuat dengan memberikan pembekalan dan membuka akses kepada mereka. Potensi pemanfaatkan kelompok perempuan dalam manajemen bencana sangat potensial, namun kesemuanya tergantung good will dari pemerintah untuk memfasilitasi hal tersebut. Disisi lain lembaga-lembaga swadaya masyarakat juga dapat menginisiasi dan melakukan pendampingan agar kelompok-kelompok perempuan dapat dijadikan sebagai salah satu saluran untuk manajemen bencana.

\footnotetext{
${ }^{10}$ Koleman adalah istilah setempat (bahasa Madura, karena sebagian besar etnis keturunan Madura) untuk menyebutkan istilah mengadiri acara hajatan misalnya acara pernikahan atau sunatan.
} 


\section{KESIMPULAN}

Terdapat beragam bentuk perkumpulan perempuan di desa Kemiri, diantaranya kelompok muslimat mingguan, muslimat triwulanan, kelompok arisan, hadrahan, dama dan juga PKK. Selain itu terdapat perkumpulan perempuan sebagai sebuah hubungan social kemasyarakatan seperti momen-momen takziyah, hajatan (rewang), sampai pada perkumpulan ibu-ibu di sekolah yang sedang mememani anaknya sekolah. Melalui forum-forum ini informasi bergulir, dan berputar di masyarakat.

Berdasarkan kondisi kultur dan struktur pada masyarakat desa Kemiri, kaum perempuan lebih banyak berkiprah pada sector domestic. Oleh karena itu, peran-peran mereka dalam proses manajemen bencana juga tidak jauh dari aktifitas domestik seperti di dapur umum, memberi pelatihan keterampilan, membuat kue, merawat yang sakit dan memberi sosialisasi melalui forum-forum solidaritas mereka. Walaupun demikian, jaringan kelompok ini dengan kelompok luar cukup kuat. Hal itu disebabkan oleh kekuatan politis, dimana beberapa kelompok ini merupakan basis massa dari suatu partai politik atau ormas di Indonesia. Akan tetapi, jalinan kerjasama dengan kelompok lain, yang berbeda manhaj tetap terjadi baik itu dalam ranah keagamaan maupun dalam ranah ekonomi.

Kekuatan jaringan kelompok-kelompok perempuan ini, akhirnya mampu menjembatani lemahnya akses-akses perempuan dalam ranah structural. Sehingga, melalui kelompok-kelompok lain yang ada di luar demografis desa Kemiri mampu menjadi bridging social capital bagi kelompokkelompok perempuan di desa Kemiri ini untuk menjangkau akses-akses (linking) struktural.

Dalam manajemen bencana yang berbasiskan masyarakat, maka pelibatan kelompok perempuan dalam manajemen bencana merupakan suatu hal yang tepat. Hal itu karena, dengan peran-peran domestik yang selama ini mereka kuasai, akhirnya menjadi suatu kekuatan atau potensi bagi mereka. Melalui forum-forum tersebut dapat juga dilakukan sosialisasi mengenai kebencanaan. Bahkan kelompok-kelompok perempuan ini dapat bergabung dalam suatu ikatan yang khusus menanangani masalah kebencanaan. Misalnya kelompok Prempuan Siaga Bencana. Melalui kelompok ini dapat dilakukan analisa mengenai kerentanan perempuan terhadap bencana, pelatihan kebencanaan, informasi kebencanaan, pusat penggalangan bantuan untuk perempuan korban bencana, dan jika perlu mereka mempunyai radio khusus untuk memberikan informasi dan pengetahuan tentang kebencanaan. Dimana kesemuanya itu dapat dilakukan dengan kerjasama dari berbagai elemen kelompok perempuan sekabupaten.

\section{DAFTAR PUSTAKA}

Awotona, Adenrele (ed.).1997. Reconstruction after disaster: issues and practices. Aldershot, Ashgate.

Badaruddin. (2006). Modal sosial dan pengembangan model transmisi modal sosial dalam upaya peningkatan kesejahteraan keluarga (Studi pada_ga komunitas petani karet di Kecamatan Rao Kabupaten Pasaman Sumatera Barat). Naskah tidak diterbitkan, Penelitian Hibah Bersaing Perguruan Tinggi, Dikti.

Bakornas PBP. 2005. Panduan Pengenalan Karakteristik Bencana dan Upaya Mitigasinya di Indonesia. Jakarta:Biro Mitigasi Badan Koordinasi Nasional Penanggulaangan Bencana dan Penanganan Pengungsi.

BNPB. 2008. Data Bencana Indonesia Tahun 2008. Jakarta: pusdatinhumas BNPB

Bourdieu, P. 1986. The Form of Capital. In J. Richardson (Ed). Handbook of Theory and Research for Sociology of Education. New York: Greenwood Press. 
Carmelita, M. 2002. Faktor-faktor yang Berhubungan dengan Pola Komunikasi Kelompok pada Proses Pengambilan Keputusan Inovasi. Tesis pada Sekolah Pascasarjana IPB, Bogor

Coleman, James S. 1988. Foundations of Social Theory. Cambridge. Harvad University Press

Creswell, Jhon W. 1994. Research Design: Qualitative and Quantitative Approaches. Sage Publications

Suyanto, Bagong, dkk. 2010. Metode Penelitian Sosial: Berbagai Alternatif Pendekatan. Jakarta: Kencana

Fukuyama, Francis. 1995. Trust: The Social Virtues and The Creation Of Prosperity. New York. The Free Press

Pusat Vulkanologi dan Mitigasi Bencana Geologi - ESDM. 2006. Pengenalan Gempa Bumi. Jakarta: Departemen ESDM.

Santosa, S. 2004. Dinamika Kelompok. Jakarta: Bumi Aksara.

UNDP. 1992. Tinjauan Umum Manajemen Bencana. Jakarta: Modul Pelatihan Manajemen Bencana UNDP/UNDRO.

Winardi, Rahardjo, dkk. 2006. Gempa Jogja, Indonesia dan Dunia. Jakarta : PT Mediarona Dirgantara.

\section{Jurnal:}

Heru Sri Naryanto, dkk .2007. Potensi Longsor dan Banjir Bandang serta Analisis Kejadian Bencana 1 Januari 2006 di Pegunungan Argopuro, Kabupaten Jember. Alami Vol. 12 No.2 Tahun 2007

Hidayati, D. 2005. Panduan Siaga Bencana Berbasis Masyarakat. Jurnal Komunika 8 (1), IDEP. 2005. Penanggulangan Bencana Berbasis Masyarakat. Yayasan IDEP, Bali ISDR Informs, Edisi 2 Tahun 2006

Ibrahim, L. D. (2006). Memanfaatkan modal social komunitas lokal dalam program kepedulian korporasi. Jurnal Filantropi dan Masyarakat Madani GALANG, 1(2): 19-28.

\section{Internet:}

Agnes mawarni (2010) tentang Pentingnya modal sosial dalam pembangunan pasca bencana. http://www.pspk.ugm.ac.id/artikel-terbaru/ 81 -pentingnya-modal-sosial-dalampembangunan-pasca-bencana.html
Agus, Supriono, dkk. Modal Sosial: Definisi, Demensi, dan Tipologi. http://www.google.co.id/ search?q=kapital + sosial $\% 2 \mathrm{C}+$ woolcock $\%$ $2 \mathrm{C}+2000$.

Fadli. 2007. Peran modal sosial dalam percepatan Pembangunan desa pasca tsunami (Kasus pembangunan perumahan dan peningkatan Pendapatan Keluarga di Beberapa Desa di Kabupaten Aceh Besar). http:// repository. ipb.ac.id/bitstream/handle/.../Cover $\% 20 \%$ 202007fad.pdf?...6

Hawkins dan Maurer, 2009. Dalam http://zanikhan. multiply.com/journal/item/12952 http://birohumas.jatimprov.go.id/index.php/ component/content/article/34-berita-humas/ 336-ketua-tp-pkk-prov-jatim-programkb-banyak-diminati-masyarakat-perkotaan

http://hagemman.wordpress.com/2010/01/02/ buta-aksara-masih-didominasi-perempuan/

http://tabloid_info.sumenep.go.id/index.php? option $=$ com_content\&task $=$ view $\&$ id $=293$ \&Itemid $=30$

http://www.tulungagung.go.id/index.php/ berita/itemlist/tag/Dinas\%20Kesehatan? limit $=10 \&$ date $=2010-06-01$

http://birohumas.jatimprov.go.id/index.php/ component/content/article/34-berita-humas/ 336-ketua-tp-pkk-prov-jatim-programkb-banyak-diminati-masyarakat-perkotaan

http://masroed.wordpress.com/2010/05/26/ pengaruh-dan-wujud-pengembangan-modalsosial-untuk-menciptakan-sistem-politikyang-dinamis/

http://wartawarga.gunadarma.ac.id/2010/04/ pengertian-manusia-sebagai-mahluk-yang-hidupberkelompok/ terakhir diakses 10 April 2012 http://www.asrori.com/2011/11/arisan-sebagaiorganisasi-sosial.html.

Imam Yudhianto Soetopo. Penanganan bencana berperspektif gender. http:/www.lintasberita.com/ Lifestyle/Pendidikan/penanganan-bencanaberperspektif-gender.

Ismay Prihastuti. 09 September 2009. Perempuan dan kebencanaan. http://www.lp3y.org/ pdf.php?pilih $=$ newsletter\&id $=177$

Mauludi, 2008, tentang Pemanfaatan modal sosial dalam rekonstruksi sosial ekonomi pasca gempa bumi dan gelombang tsunami di Aceh. http://repository.usu.ac.id/bitstream/ 123456789/7230/1/09E01973.pdf 
Prasetyo, H. 2004. Manajemen Bencana. Dokumen http://www.walhi.or.id. http://www.nttacademia.org/Modul-CBDRM/Modul2.2Pe ngelanan-CBDRM-Framework.pdf.

Rudy Pramono. 2008. http://www.google.co.id/ search?hl=id\&client=firefox-a\&rls=org. $\mathrm{moz}$ illarudy+pramono $\% 2 \mathrm{C}+$ kapital + sosial + pasc a+bencana

Tamrin, Husni. dkk. Implementasi Corporate Social Responsibility Berbasis Modal Sosial di Sumatera Utara. http://www.coveragefikomup.com/pdf/ Coverage_I_006.pdf.

Michael Woolcock and Deepa Narayan. 2000. Social Capital: Implications for Development Theory, Research, and Policy. Final version submitted to the World Bank Research Observer To be published in Vol. 15(2). deepanarayan.com/pdf/papers/woolcock.pdf

\section{Proceeding:}

Handayani, Baiq Lily. 2013. The Role of Womens Group on Recontruction Social System in Relocation Post of The Flash Flood Disaster in Desa Kemiri, Panti, Jember. Proceeding IGSCI 2013. Hal. 305

Handayani, Baiq Lily. 2016. Aplikasi Nilai-Nilai Islam Dalam Wadah Kelompok Pengajian Muslimat Sebagai Upaya Recovery Pasca Bencana. Buku KIPI 3. Universitas Jember. Hal 495.

Handayani, Baiq Lily. 2013. The Power Of Powerless (Role Of Women's Group On Disaster Management). Proceeding ICOCSPA 2016. Hal. 311

\section{Laporan Penelitian:}

Handayani, Baiq Lily. dkk. 2011. Studi peran kelompok perempuan dalam manajemen bencana di kecamatan Panti kabupaten Jember. BNPB. Laporan penelitian Tidak diterbitkan.

Handayani, Baiq Lily. 2012. Jaringan Kelompok perempuan sebagai modal social yang potensial dalam manajemen bencana di desa kemiri kecamatan Panti Jember. Tesis Universitas Airlangga, tidak diterbitkan.

Handayani, Baiq Lily. 2013. Kapasitas Kelompok Perempuan dalam Manajemen Bencana Berbasis Masyarakat di Lingkungan Kauman Kab. Jember. Laporan Hasil Penelitian Universitas Jember. Tidak diterbitkan.

Handayani, Baiq Lily. 2015. Kesiapsiagaan Kelompok Perempuan dalam Menghadapi bencana di Kab. Jember. Laporan Hasil Penelitian Universitas Jember. Tidak diterbitkan. 